\section{Biofouling}

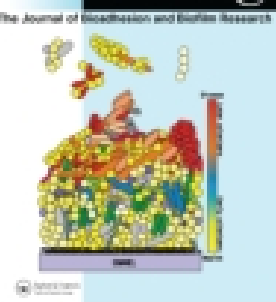

Biofouling

ISSN: 0892-7014 (Print) 1029-2454 (Online) Journal homepage: http://www.tandfonline.com/loi/gbif20

\title{
Oxygen and $\mathrm{pH}$ microprofiles above corroding mild steel covered with a biofilm
}

\section{Whonchee Lee \& Dirk de Beer}

To cite this article: Whonchee Lee \& Dirk de Beer (1995) Oxygen and pH microprofiles above corroding mild steel covered with a biofilm, Biofouling, 8:4, 273-280, DOI:

$10.1080 / 08927019509378280$

To link to this article: http://dx.doi.org/10.1080/08927019509378280

册Published online: 10 Jan 2009.

Submit your article to this journal $\pi$

Џ Article views: 28

Q View related articles $\asymp$

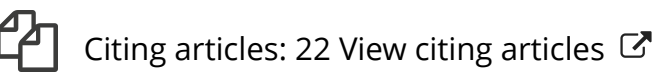




\title{
OXYGEN AND pH MICROPROFILES ABOVE CORRODING MILD STEEL COVERED WITH A BIOFILM
}

\author{
WHONCHEE LEE* and DIRK de BEER \\ Center for Biofilm Engineering, 409 Cobleigh Hall, Bozeman, MT 59715, USA
}

(Received 15 June 1994; in final form 15 October 1994)

\begin{abstract}
$\mathrm{O}_{2}$ and $\mathrm{pH}$ microprofiles were measured above corroding mild steel covered with a biofilm. The $\mathrm{pH}$ in the anodic areas (tubercles) ranged from 5 to 7 and was always 9.45 at the surface of the cathodic areas. After 1 month of biofilm development, $\mathrm{O}_{2}$ was depleted at the anodic area but could reach the cathodic surface where it was reduced. Consequently, differential $\mathrm{O}_{2}$ concentration cells were the driving force for corrosion. The $\mathrm{O}_{2}$ microprofiles indicated that $\mathrm{O}_{2}$ was consumed in the tubercles, probably by microbial activity, while $\mathrm{O}_{2}$ was reduced electrochemically in the cathodic areas. It was concluded that $\mathrm{O}_{2}$ transfer to the cathodic surface was the rate limiting step for the corrosion process.
\end{abstract}

KEYWORDS: biofiIm, corrosion, microelectrode, tubercle, mild steel

\section{INTRODUCTION}

Mild steel, commonly used in the industrial water systems, is prone to corrosion. The corrosion products, deposited on the steel surface, consist of three layers of iron oxides at different stages of oxidation, viz. ferrous hydroxide $\left(\mathrm{Fe}(\mathrm{OH})_{2}\right)$, hydrous ferrous ferrite $\left(\mathrm{Fe}_{3} \mathrm{O}_{4} \cdot \mathrm{nH}_{2} \mathrm{O}\right)$ and hydrous ferric oxyhydroxide $\left(\mathrm{FeOOH} . \mathrm{H}_{2} \mathrm{O}\right)$ (Uhlig, 1971; Misawa, 1973). The general corrosion rate is determined by the rate of $\mathrm{O}_{2}$ reduction. Since $\mathrm{O}_{2}$ is transported from the bulk liquid through the porous layers of corrosion products to the steel surface, corrosion rates are limited by 1) the $\mathrm{O}_{2}$ consumption rate by microbial activity in the layer of corrosion products and the biofilm covering the steel surface and/or 2) the diffusional resistance in the layer of corrosion products (Bonnel et al., 1983). Passivation of mild steel occurs at very high $\mathrm{O}_{2}$ concentrations, but does not take place under air saturated conditions (Uhlig, 1971). In its initial stage, corrosion of mild steel is a localized process but eventually involves the whole surface (Szklarska-Smialowska, 1986).

The most dangerous form of localized corrosion of mild steel is tuberculation. According to Herro (1991), tubercle formation originates from a differential $\mathrm{O}_{2}$ concentration cell. Local $\mathrm{O}_{2}$ depletion can occur under a non-uniform biofilm. $\mathrm{O}_{2}$ reduction occurs in the cathodic area and produces hydroxyl ions, while in the anodic area (the tubercle) iron dissolution occurs. Due to hydrolysis by $\mathrm{Fe}^{2+}$ and formation of $\mathrm{Fe}(\mathrm{OH})_{2}$, protons are formed, leading to a low $\mathrm{pH}$ within the tubercle. The $\mathrm{Fe}^{2+}$ generation prompts an anion flux into the tubercle to maintain electro-neutrality. Pitting corrosion beneath the tubercle is suggested to be a transport controlled process (Butler \& Ison, 1966), whose rate is determined by the ion mobility through the corrosion products. The present objective was to verify this mechanism in the presence of microorganisms by

*Corresponding author. 
measurement of $\mathrm{O}_{2}$ and $\mathrm{pH}$ microprofiles with microelectrodes at cathodic areas and within tubercles covered with biofilm.

Ideal microelectrodes have small tip diameters to prevent distortion of the local environment, small sensor surfaces for optimal spatial resolution, low noise levels, a stable signal, high selectivity and should be strong enough to resist breakage during the measurements. The relatively rigid cathode type $\mathrm{O}_{2}$ microelectrodes are suitable for measurements on solid surfaces (Revsbech, 1983). No ideal $\mathrm{pH}$ electrode is available at the present time. Different types of $\mathrm{pH}$ microelectrodes have been used for microprofile determinations in sediments (Revsbech \& Jorgensen, 1986) and in biofilms from bioreactors (de Beer et al., 1993; de Boer et al., 1993). Full glass pH microelectrodes are highly selective, but have a large sensor surface, with a length of at least $30 \mu \mathrm{m}$ (Thomas, 1978; Revsbech \& Jorgensen, 1986). Metal iridium oxide microelectrodes are sturdy and have a low noise sensitivity, enabling measurements in reactors (VanHoudt et al., 1992), but their signal is influenced by $\mathrm{Fe}^{+2}$ and $\mathrm{S}^{-2}$, and the iridium oxide layer may detach upon touching a solid surface, leading to an unstable signal. The signal of liquid membrane microelectrodes is hardly influenced by interfering substances. However, due to their small size the electrodes are fragile and very sensitive to noise. The maximum tip diameter is about $3 \mu \mathrm{m}$, larger capillaries lose their membrane easily because of the lower capillary force. For $\mathrm{pH}$ determinations at steel surfaces covered with partially anaerobic biofilm liquid membrane microelectrodes are preferred, because of their insensitivity to $\mathrm{Fe}^{2+}$ and $\mathrm{S}^{--}$. The behavior of larger, and thus stronger, liquid membrane microelectrodes was tested, with membranes stabilized by solidification.

\section{EXPERIMENTAL}

Detailed descriptions of the experimental system and operating conditions are presented in previous papers (Lee et al., 1993a,b; Nielsen et al., 1993). Mild steel coupons were placed in a closed flow channel reactor with a recirculation loop to provide sufficient mixing. The average flow velocity was $0.3 \mathrm{~m} \cdot \mathrm{s}^{-1}$. The reactor was operated as a continuous flow reactor at a dilution rate of $0.4 \mathrm{~h}^{-1}$. Twenty four corrosion coupons (AISI 1018 mild steel, $15.9 \mathrm{~mm}$ diameter) were mounted into the bottom of the reactor. The temperature was controlled at $30^{\circ} \mathrm{C}$. The medium consisted of $0.35 \mathrm{~g} \cdot 1^{-1}$ artificial seawater (Instant Ocean, aquarium Systems, Mentor, $\mathrm{OH}), 1.0 \mathrm{mg} \cdot \mathrm{l}^{-1}$ sodium lactate,

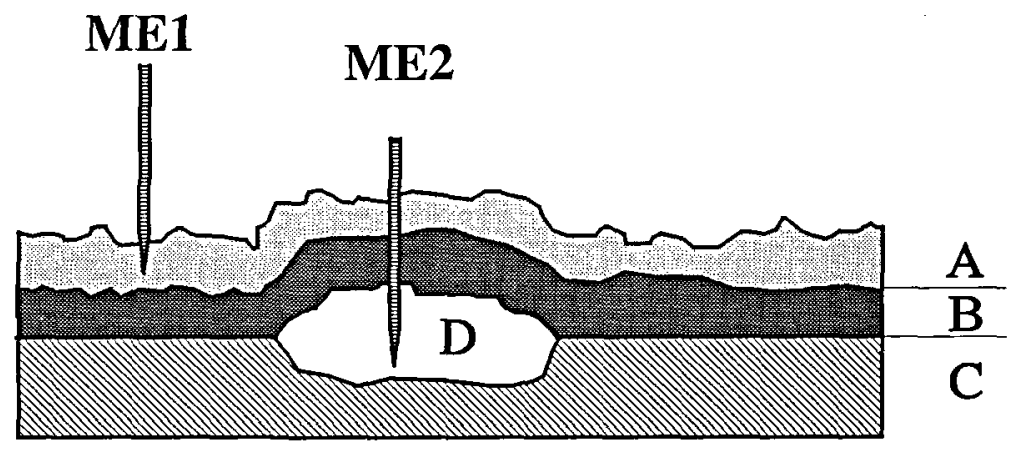

Fig. 1 Schematic diagram of corroding mild steel. $\mathrm{A}=$ the biofilm; $\mathrm{B}=$ the layer of corrosion product; $\mathrm{C}=\mathrm{the}$ metal; $\mathbf{D}=$ the pit below the tubercle. Also shown are microelectrodes positioned in the cathodic area (ME1) and in the pit below the tubercle (ME2). 
$1.0 \mathrm{mg} \cdot \mathrm{l}^{-1} \mathrm{NH}_{4} \mathrm{Cl}$, and $20 \mathrm{mg} \cdot \mathrm{l}^{-1} \mathrm{Na}_{2} \mathrm{HPO}_{4}$. The $\mathrm{pH}$ in the bulk was 7.5 and the bulk $\mathrm{O}_{2}$ concentration was $0.25 \mathrm{~mol} \cdot \mathrm{m}^{-3}$. Pseudomonas aeruginosa, Klebsiella pneumonia, and Desulfovibrio desulfuricans were used as inocula but the reactor was not run aseptically. Microprofile measurements were performed after 1 month of biofilm development. The diameters of the tubercles then ranged from 1-3 mm. The tubercles covered $c a 20 \%$ of the metal surface. A schematic representation of a tubercle is given in Figure 1.

\section{Microelectrodes}

A cocktail was prepared containing $12 \%$ hydrogen ionophore II, $2 \%$ potassium tetrakis (4-chlorophenyl)borate, $60 \%$ 2-nitrophenyl octyl ether, $22 \%$ poly-vinyl chloride (high molecular weight) and $4 \%$ cellulose acetate. The cocktail was dissolved in approximately 5 volumes of tetrahydrofuran (THF). All chemicals were obtained from Fluka Chemical Corporation, New York. Glass tubing of $5 \mathrm{~mm}$ diameter was drawn in a flame to capillaries $1 \mathrm{~mm}$ thick. Subsequently, microtips were drawn using an automatic vertical puller (model 51217, Stoelting Company). The tip was opened by careful pushing against a glass rod using a micromanipulator, resulting in a final tip diameter of $5-10 \mu \mathrm{m}$. The tips were silanized by dipping in 5\% trimethylchlorosilane in carbon tetrachloride for $15 \mathrm{~s}$, followed by baking at $175^{\circ} \mathrm{C}$ for $10 \mathrm{~min}$. The electrode tips were filled with sensor by dipping the tips in the cocktail. After filling, the electrodes were left overnight in a dust free container at room temperature to let the THF evaporate, leaving a solid $\mathrm{pH}$ sensitive membrane in the tip. The electrode shaft were filled with $50 \mathrm{mM}$ sodium phosphate buffer ( $\mathrm{pH} 7.0$ ) supplemented with $300 \mathrm{mM} \mathrm{KCl}$. Electrical connection was made with a $\mathrm{Ag} / \mathrm{AgCl}$ wire. The electrode potential difference with an $\mathrm{Ag} / \mathrm{AgCl}$ reference electrode was measured with a Keithley 617 electrometer. Calibration of the microelectrodes was performed in a buffer containing $50 \mathrm{mM}$ sodium phosphate, $50 \mathrm{mM}$ sodium citrate and $50 \mathrm{mM}$ sodium borate. The buffer was titrated with $1 \mathrm{M} \mathrm{HCl}$ or $1 \mathrm{M} \mathrm{NaOH}$ and the microelectrode signal was compared with the $\mathrm{pH}$ of the solution measured with a normal glass $\mathrm{pH}$ macroelectrode. Iridium oxide $\mathrm{pH}$ microelectrodes and cathode type $\mathrm{O}_{2}$ microelectrodes were prepared and calibrated as described previously (Revsbech, 1983; VanHoudt et al., 1992).

\section{Microprofile Measurements}

The microelectrodes were mounted on a motor-driven micromanipulator with a $1 \mu \mathrm{m}$ accuracy. Corroding coupons were removed from the channel reactor and mounted in a polycarbonate batch reactor $(1 \times \mathrm{w} \times \mathrm{h}=10 \times 10 \times 3 \mathrm{~cm})$, so that their surface was flush with the reactor bottom. The reactor liquid was obtained form the channel reactor and sparged with air in one of the corners for aeration and circulation of the reactor liquid. The biofilm surface was determined optically, while the steel surface was determined as the position where bending of the electrodes occurred. Additionally, $\mathrm{O}_{2}$ and $\mathrm{pH}$ profiles were determined in the channel reactor, using $\mathrm{O}_{2}$ and iridium oxide $\mathrm{pH}$ microelectrodes.

\section{RESULTS AND DISCUSSION}

The PVC-solidified liquid membrane remained firmly attached in the tip of relatively large microelectrodes with tip diameters of 5-10 $\mu \mathrm{m}$. Membranes without PVC addition disappeared during filling of the shaft with electrolyte. The electrodes were more sturdy than those of microelectrodes with $1 \mu \mathrm{m}$ tips and remained intact after touching a solid 


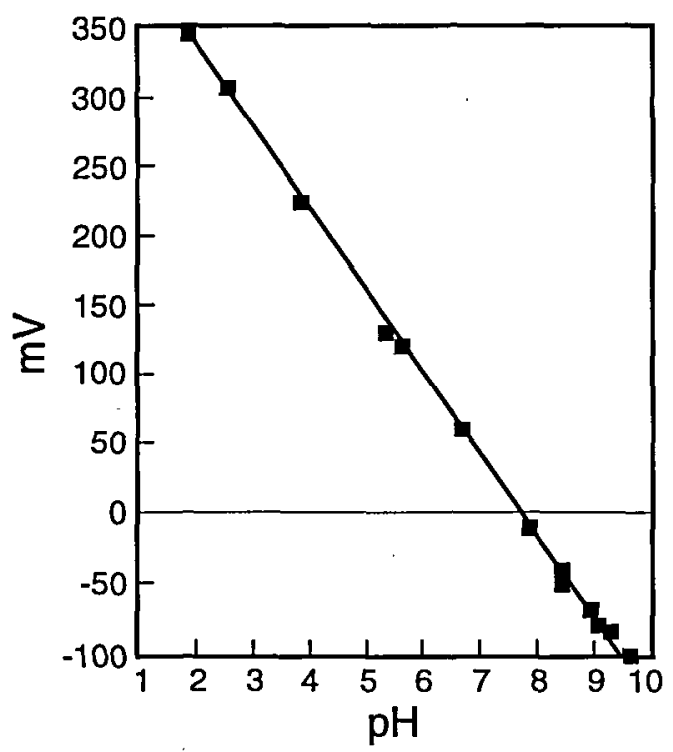

Fig. 2 Calibration curve of $\mathrm{pH}$ microelectrode with solidified liquid membrane.

surface. The response of the microelectrodes to $\mathrm{pH}$ values in the range of 1.5 to 9.5 was linear with slopes of $50-58 \mathrm{mV} / \mathrm{pH}$ (Fig. 2). The response time $\left(\mathrm{t}_{90}\right)$ was approximately $1 \mathrm{~s}$. The signal drifted less than $3 \mathrm{mV} \cdot \mathrm{h}^{-1}$ during measurements. The calibration line was not influenced by addition of $20 \mathrm{mM} \mathrm{Na}_{2} \mathrm{~S}$ or $10 \mathrm{mM} \mathrm{FeSO}_{4}$. Their mechanical strength and high selectivity coefficients enabled measurements near a mild steel surface covered with a biofilm containing sulfate-reducing bacteria. However, the design of the microsensor may be improved to reduce to noise sensitivity, e.g. by encasing the shaft in metal or inserting the electrode in another capillary filled with $\mathrm{KCl}$ as a shielding. At present, its use is restricted to areas with low noise levels such as a Faraday cage.

\section{Microprofiles Measured in the Batch Cell}

The $\mathrm{pH}$ values on the mild steel coupon surface were strongly influenced by the presence of tubercles as shown by $\mathrm{pH}$ microprofiles in the batch reactor. The microprofiles around the tubercle (cathodic site) consistently showed a $\mathrm{pH}$ increase ranging from $\mathrm{pH}$ 7.5-8.0 in the bulk liquid to 9.5 on the steel surface (Fig. 3). Profiles measured above tubercles (anodic site) were more variable but always showed a $\mathrm{pH}$ decrease in the direction toward the tubercle surface (Fig. 3). The pH values on the surface of the tubercles ranged from 5 to 7 . The high $\mathrm{pH}$ value on the cathodic site and the low $\mathrm{pH}$ value toward the anodic site can be explained by corrosion reactions. During the tubercle formation, hydroxyl ions are generated at the cathodic site by $\mathrm{O}_{2}$ reduction. The hydroxyl ions combined with ferrous ions migrating from the anodic site to form $\mathrm{Fe}(\mathrm{OH})_{2}$. The ferrous hydroxide layer forms a diffusion barrier for $\mathrm{O}_{2}$ and other reactants. The $\mathrm{pH}$ value of a saturated $\mathrm{Fe}(\mathrm{OH})_{2}$ solution is 9.45 , a value measured at the steel surface in the cathodic zones. The acidity within the tubercle is caused by the hydrolysis of ferrous or ferric ions and persists because of the restricted mass transfer imposed by a porous cap of corrosion products. The irregular 


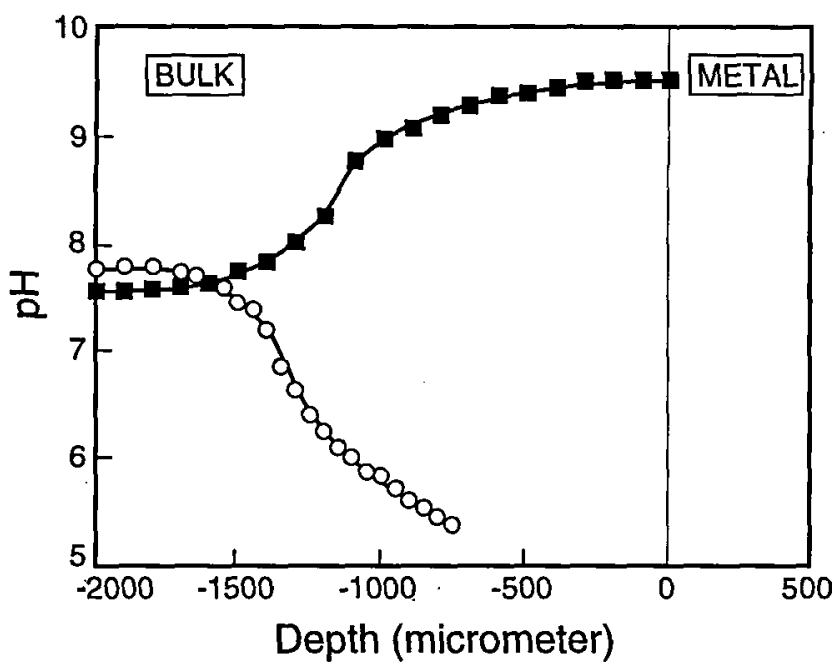

Fig. $3 \mathrm{pH}$ profiles measured above corroding mild steel covered with a $1 \mathrm{~mm}$ thick biofilm. $\bigcirc-\bigcirc=$ profiles measured above a $0.75 \mathrm{~mm}$ thick tubercle; $\mathbf{-}=$ profiles measured above the cathodic area between the tubercle. Microprofiles were recorded down to the solid surface but the microelectrode did not penetrate the tubercle.

occurrence of cracks in the tubercle resulted in variable permeability. Therefore, $\mathrm{pH}$ concentrations showed a greater variation above the tubercle than around the tubercle areas.

The significant differences in $\mathrm{pH}$ on the surface of a corroding mild steel offer an opportunity for monitoring pitting corrosion. Tubercles can be detected by their low $\mathrm{pH}$ value. Instead of using $\mathrm{pH}$ microelectrodes, detection with $\mathrm{pH}$ indicator dyes may be a more attractive alternative for routine measurements.

$\mathrm{O}_{2}$ microprofiles showed consumption both on anodic and cathodic sites. The concentration at the cathodic surface was usually close to $0.05 \mathrm{~mol} \cdot \mathrm{m}^{-3}$, but some measurements showed surface concentrations of $0.0 \mathrm{~mol} \cdot \mathrm{m}^{-3}$ (Fig. 4). The $\mathrm{O}_{2}$ microprofiles above the cathodic area consisted of two or three almost perfectly linear parts (Fig. 4) $\mathrm{O}_{2}$ can be consumed by microbial activity in the biofilm and by electrochemical reduction at the steel surface. Lactate was the sole carbon source and assuming microbial lactate oxidation was the only $\mathrm{O}_{2}$ consuming process, the $\mathrm{O}_{2}$ concentration in the biofilm was calculated as follows

$$
C_{O}=C_{B O}-Y\left(C_{B l a c}\right)\left(\frac{D_{l a c}}{D_{O}}\right)
$$

where $C_{O}$ is the local $\mathrm{O}_{2}$ concentration, $Y$ the moles of $\mathrm{O}_{2}$ necessary to oxidize one mole of lactate $(Y=3), C_{B O}$ the $\mathrm{O}_{2}$ bulk concentration, $C_{B l a c}$ is the lactate bulk concentration and $D_{l a d} / D_{o}$ is the ratio of the diffusion coefficients of lactate and $\mathrm{O}_{2}$. A value for $D_{\text {lac }}$ of $1.05 \times 10^{-9} \mathrm{~m}^{2} \cdot \mathrm{s}^{-1}$ was calculated using the Wilke-Chang equation (Treybal, 1981) and $\mathrm{D}_{\mathrm{o}}$ was $2.33 \times 10^{-9} \mathrm{~m}^{2} \cdot \mathrm{s}^{-1}$ (Andrussow, 1969). From the bulk liquid concentrations of lactate (less than $\left.10^{-2} \mathrm{~mol} \cdot \mathrm{m}^{-3}\right)$ and $\mathrm{O}_{2}\left(0.25 \mathrm{~mol} \cdot \mathrm{m}^{-3}\right)$, it was calculated that the lowest possible $\mathrm{O}_{2}$ concentration in the biofilm will be $0.236 \mathrm{~mol} \cdot \mathrm{m}^{-3}$ if microbial lactate oxidation was the only oxygen consuming process. The measured $\mathrm{O}_{2}$ concentrations in the biofilm were much lower, therefore, microbial $\mathrm{O}_{2}$ consumption by substrate from the bulk was 


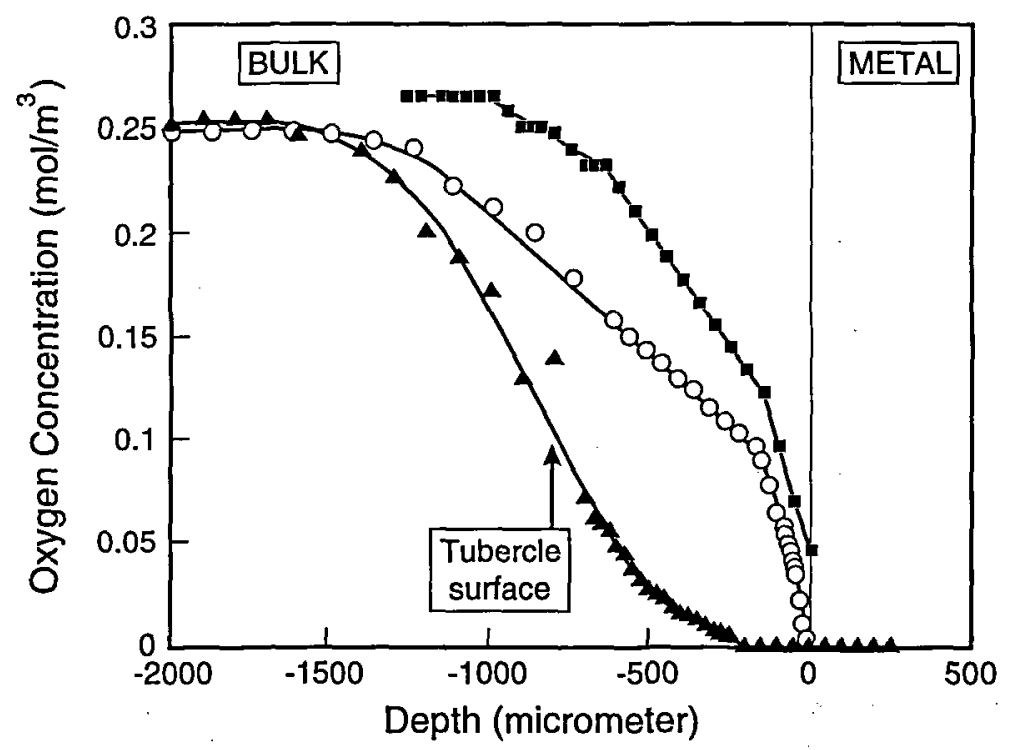

Fig. $4 \mathrm{O}_{2}$ profiles measured above the same mild steel surface as in Figure $3 . \mathbf{\Lambda}-\mathbf{A}=$ profiles measured above a tubercle; $\mathrm{O}-\mathrm{O}$ and $\boldsymbol{\square}-\mathbf{\square}=$ profiles measured above cathodic areas. The microelectrode could penetrate the tubercle and reach the pit.

insignificant in the cathodic region. Alternatively, microbial $\mathrm{Fe}^{2+}$ oxidation might occur above the cathodic area. However, $\mathrm{Fe}^{2+}$ oxidising bacteria are acidophilic (Schlegel, 1981) while the local $\mathrm{pH}$ is high. Moreover, the linearity of the $\mathrm{O}_{2}$ microprofiles indicate negligible $\mathrm{O}_{2}$ consumption by the biofilm covering the steel surface. The shape of the microprofiles is consistent with the explanation that $\mathrm{O}_{2}$ was almost exclusively reduced electrochemically at the cathodic site. The differences in the gradients of the linear parts indicate the existence of multiple layers with different diffusivities covering the steel surface. Since the $\mathrm{O}_{2}$ fluxes below and above the deflection points were equal, the ratio of the $\mathrm{O}_{2}$ gradients was equal to the ratio of the diffusion coefficients. It was estimated that the $\mathrm{O}_{2}$ diffusion coefficient in the outermost layer was 3 to 10 times higher than in the adjacent layer closer to the steel surface. In a number of experiments a second deflection point was observed, indicating the existence of a third layer adjacent to the steel surface, with a lower diffusion coefficient than the two upper layers. In these experiments complete depletion of $\mathrm{O}_{2}$ at the steel surface was found. Probably, the bottom layer was relatively dense and could not always be penetrated by microelectrodes. The layer covering the cathodic areas, probably consisting mainly of corrosion products and biofilm, decreased the $\mathrm{O}_{2}$ flux towards the surface, thereby reducing the corrosion rate.

The $\mathrm{O}_{2}$ profile above the tubercles showed more variation and the tubercle surface concentration ranged from $0.1-0.2 \mathrm{~mol} \cdot \mathrm{m}^{-3}$. The irregularity was probably due to turbulent hydrodynamics caused by the uneven tubercle surface and by cracks in the tubercle. When the $\mathrm{O}_{2}$ microelectrode could penetrate through a crack into the tubercle, lower $\mathrm{O}_{2}$ concentrations were detected and non-linear profiles within the tubercle were recorded (Fig. 4), typical for matrices with active microorganisms. The $\mathrm{O}_{2}$ profile measured down tot he bottom of the pit showed depletion $250 \mu \mathrm{m}$ above the steel surface. The shape of the profiles can be explained by a flux of reducing species, such as $\mathrm{H}_{2}, \mathrm{~S}^{2-}$ or $\mathrm{Fe}^{2+}$, diffusing 
from the bottom of the pit towards the bulk liquid. Consequently, microbial population above a tubercle can feed on different substrates and may have a different composition than above cathodic areas, which grow only on substrates from the bulk liquid.

\section{Microprofiles Measured in the Channel Reactor}

The solidified liquid membrane microelectrode appeared too noise-sensitive for measurements in the channel reactor and the electrode could only be used in the batch reactor. Although the medium was the same in both systems, the $\mathrm{pH}$ profiles could be different due to different flow regimes. To examine whether the $\mathrm{pH}$ profiles measured in the batch reactor are representative for profiles occurring in the channel reactor, $\mathrm{O}_{2}$ profiles were measured in both experimental systems and compared. $\mathrm{O}_{2}$ profiles measured on the same coupon, first in the channel reactor, then in the batch cell, were similar (data not shown), demonstrating comparable hydrodynamics. This was further supported by $\mathrm{pH}$ profiles measured in the channel reactor with an iridium oxide microelectrode, showing a $\mathrm{pH}$ increase to $\mathrm{pH} 9$ at the surface of the cathodic zone and a $\mathrm{pH}$ decrease to pH 6 at the surface of a tubercle (data not shown). It was concluded that the pH profiles in the batch reactor were identical to those in the channel reactor.

\section{CONCLUSIONS}

The $\mathrm{pH}$ was 9.45 at the cathodic surface and 5-7 at the tubercle surface. $\mathrm{O}_{2}$ was depleted above the anodic sites but could reach the cathodic surface, where it was reduced. Differential $\mathrm{O}_{2}$ concentration cells were the driving force for the corrosion process. $\mathrm{O}_{2}$ transfer to the cathodic surface was the rate limiting step, due to mass transfer resistance in the layer of corrosion products and biofilm covering the cathodic area.

\section{References}

Andrussow, L. (1969) Diffusion. In: Landolt-Bornstein Zahlenwerte und Functionen II/5a. Springer, Berlin, pp 513-727.

Bonnel A, Dabosi F, Deslouis C, Duprat M, Keddam M, Tribollet B J (1983) Corrosion study of a carbon steel in natural chloride solutions by impedance techniques. J Electrochem Soc 130: 753-766

Butler G, Ison HCK (1966) Corrosion and its Prevention in Waters. Reinhold, New York, pp 45-46.

de Beer D, van den Heuvel J C, Ottengraf S P P (1993) Microelectrode measurements of the activity distribution in nitrifying bacterial aggregates. Appl Environm Microbiol 59: 573-579

de Boer J P, Cronenberg C C H, de Beer D, van den Heuvel J C, Teixeira de Mattos M J, Neijssel O M (1993) $\mathrm{pH}$ and glucose profiles in aggregates of Bacillus laevolacticus. Appl Environm Microbiol 59: 2474-2478

Herro H M (1991) Tubercle formation and growth on ferous alloys. Corrosion '9l, NACE, Houston, Texas, Paper No 84 .

Lee W, Lewandowski Z, Okabe S, Characklis W G, Avci R (1993a) Corrosion of mild steel underneath aerobic biofilms containing sulfate-reducing bacteria Part I: at low dissolved oxygen concentration. Biofouling 7: $197-216$

Lee W, Lewandowski Z, Morrisen M, Characklis W G, Avci R, Nielsen P H (1993b) Corrosion of mild steel underneath aerobic biofilms containing sulfate-reducing bacteria Part II: at high dissolved oxygen concentration. Biofouling 7:217-239

Misawa, T. (1973) The thermodynamic consideration for Fe- $\mathrm{H}_{2} \mathrm{O}$ system at $25^{\circ} \mathrm{C}$. Corros Sci 13: 659-676

Nielsen P H, Lee W, Lewandowski Z, Morrisen M, Characklis W G (1993) Corrosion of mild steel in an alternating oxic and anoxic biofilm system. Biofouling 7: 267-284

Revsbech N P (1983) In situ measurement of oxygen profiles of sediments by use of oxygen microelectrodes. In: Graigner E, Forstner H (eds) Polarographic Oxygen Sensors: Aquatic and Physiological Applications. Springer, Heidelberg

Revsbech N P, Jorgensen B B (1986) Microelectrodes: their use in microbial ecology. Adv Microbial Ecol 9: 
293-352

Schlegel H G (1981) Allgemeine Mikrobiologie. Thieme Verlag. Stuttgart, pp 345-346

Szklarska-Smialowska Z (1986) Pitting corrosion of metals. Corrosion '86, NACE, Houston, Texas pp 3-5

Thomas R C (1978) Ion-selective Intracellular Microelectrodes. How to Make and Use them. Academic Press, London

Treybal R E (1981) Mass Transfer Operations. 3th edition, McGraw-Hill

Uhlig H (1971) Corrosion and Corrosion Control: an Introduction to Corrosion Science and Engineering. 2nd Edition, Wiley \& Sons, New York, pp 91-126.

VanHoudt P, Lewandowski Z, Little B (1992) Iridium oxide $\mathrm{pH}$ microelectrode. Biotechnol Bioeng 40: 601-608 